\title{
TO THE PROBLEMS OF TOXICITY TESTING OF NANORIZED OBJECTS (Liłerature review)
}

\author{
O. Leonenko \\ State Institution "Kundiiev Institute of Occupational Health of the National Academy \\ of Medical Sciences of Ukraine", Kyiv, Ukraine
}

\begin{abstract}
Aim of the Research. To present and summarize data on the problems of assessing the toxicity and hazards of nanosized particles due to the peculiarities of their activity and variability, which prove the need to develop a vector of research in vitro.

Materials and Methods. Targeted testing can provide broad coverage of nanoproducts, reduce the cost and time of research, as well as the number of animals used in experiments. Various model test systems are proposed for use, the use of which is possible to detect harmful effects of man-made nanomaterials, and also for other chemicals: cellular and subcellular elements (mitochondria, microsomes, DNA, chorioallantoic membrane vessels), organs of laboratory animals, the simplest (unicellular) organisms, microorganisms, various aquatic organisms, plants, insects, sperm of cattle.

Biotesting is one of the methods of research in the field of toxicology, used to determine the degree of toxic effects of chemical, physical and biologically unfavorable factors that are potentially dangerous to humans and components of ecosystems.

An analytical review of scientific publications was carried out using the abstract databases of scientific libraries Pub Med, Medline and text databases of scientific publishing houses Elsevier, Pub Med, Central, BMJ group as well as other VIP databases.

Results and Conclusions. Recently, publications emphasize that the manifestations of biological effects depend on changes in the characteristics and properties of nanomaterials. These facts cannot be taken into account in standard toxicological studies. One of the ways to intensify tests and reduce their cost may be the use of accelerated toxicological studies on simple biological systems (models). In this regard, the development and implementation of alternative methods in vitro has become one of the leading areas of toxicological research of nanomaterials.
\end{abstract}

Key Words: nanoparticles, toxicity, testing.

Introduction. The development and introduction of nanotechnology, as the basis for the formation of a new production system of society, is an element of the industrial revolution of the 21st century [1]. These technologies will help solve many problems, including energy supply, environmental protection, and positive developments in industry, science, technology, medicine and other sectors of the economy. According to forecasts, in the near future the production of nanomaterials, their number and variety will grow rapidly [2, 3, 4].

Over the last 30 years, thousands of species of new particles smaller than $100 \mathrm{~nm}$ have been obtained, but toxicological studies of many nanoparticles (NPs) have not been performed. Among more than 800 items of consumer goods containing woofer, the most in demand in the world are products that contain silver nanoparticles (235 items), in second place fullerenes (71), then in the list of nanopowders of titanium oxide (38), zinc oxide (29) and others. [2].

Aim of the Research. To present and summarize data on the problems of assessing the toxicity and hazards of nanosized particles due to the peculiarities of their activity and variability, which prove the need to develop a vector of research in vitro. With increasing production of nanomaterials, the assessment of their harmful effects by conventional classical toxicological methods on laboratory animals is complicated by the ambiguity of the results, significant amounts of research, high cost of work [5, 6, 7]. A significant problem in assessing the safety of nanoproducts is the instability of nanoparticles and the unpredictability of changes in their parameters, characteristics and properties, and hence the pronounced structural-dose biological effects. Therefore, it is necessary to improve scientific approaches to the study of toxicity and hazards of nanomaterials, to research and develop alternative methods of biotesting (alternative approaches to testing), in particular without the use of warm-blooded animals (non-animal methods).

Materials and Methods. Various model test systems are offered for use, the use of which is possible to detect the harmful effects of manmade nanomaterials, as well as for other chemicals: 
- cellular and subcellular elements (mitochondria, microsomes, DNA, vessels of the chorioallantoic membrane);

- organs of laboratory animals;

- laboratory animals;

- the simplest (single-celled) organisms;

- microorganisms; - various aquatic organisms;

- plants;

- insects;

- semen of cattle.

Biotesting is one of the methods of research in the field of toxicology, which is used to determine the degree of toxic effects of chemical, physical and biologically unfavorable factors that are potentially dangerous to humans and ecosystem components [8].

To assess the toxic effects of nanoscale objects, their key properties such as cytotoxicity and oxidative stress, which are considered to be determinants of the mechanism of action and the most informative indicators for identifying and predicting the degree of danger to the human body.

To detect the toxicity of nanoparticles can be used in vitro determination of the toxicity index (It) on the analyzer AT-05 (Russia) on the test object of short-term suspension culture of bull sperm. The method allows to estimate the total effect of the impact on the specified culture of the whole set of different sized toxicants present in the samples [9].

It should be noted that the modern development of nanotechnology is ahead of the development of approaches to assessing the toxicity and hazards of nanoparticles and nanomaterials. Despite numerous studies conducted in the world, the data obtained do not allow to draw definitive conclusions about the danger of these objects.

Results and Conclusions. Recently, publications emphasize that the manifestations of biological effects depend on changes in the characteristics and properties of nanomaterials. These facts cannot be taken into account in standard toxicological studies. One of the ways to intensify tests and reduce their cost may be the use of accelerated toxicological studies on simple biological systems (models). In this regard, the development and implementation of alternative methods in vitro has become one of the leading areas of toxicological research of nanomaterials.

Recommended alternative methods of toxicity assessment involve the use of different models for research. At the same time, it is noted that among the existing methods and test systems it is necessary to use those that would be the most informative, standardized, had an objective digital evaluation of the results and correlated well with the data obtained on animals. Despite the number of proposed test systems for screening the impact of nanoscale objects, the question of choosing the most sensitive of them, depending on the goals and objectives of the study.

The harmful effects of nanomaterials can be due to both the physicochemical properties of nanoparticles and the components of the composite medium [10]. However, there are no general patterns regarding their effect on the toxic properties of nanoparticles. According to strategic forecasts published by Global Industry Analysts Inc. and the National Research University Higher School of Economics [3, 11], there has been a recent trend of steady growth in the development and implementation of various nanoparticles and nanomaterials, mainly due to the rapidly growing interest in them from medicine and the electronics industry. Therefore, special attention is paid to the safety and potential risks of objects resulting from the use of nanoand biotechnology. Due to the large number and variability of the characteristics and properties of new nanoscale agents, it is necessary to develop approaches to accelerated testing and assessment of their potential toxicity.

Assessing the danger of new chemicals and their compounds of nanoscale quantities raised two questions. First, nanomaterials have characteristics that did not exist before and for which test methods have not been developed [12]. Modern technologies, which create and develop materials in the nanometer range, require testing of their toxicity, which is difficult to implement within existing approaches to assess the danger of macro-objects. The toxic properties of a nanosized material are likely to depend on its physical characteristics and not on the toxic properties of the substance itself or the element of which the material is composed, as in the case of titanium or carbon. With the new approach to testing, nanoscale materials can be studied using in vitro tests specifically designed to detect putative biological perturbations. Nanoscale materials may require targeted testing in animal models to ensure that all biologically significant effects are identified. Secondly, due to the 
annual replenishment of the market with new chemicals, there is a need to quickly monitor their potential toxicity. This will be possible due to in vitro tests with high and medium throughput to assess the safety of nanomaterials and excipients, as well as the products of their interaction by deciphering molecular and cellular mechanisms $[13,14]$.

Model studies have shown that the interaction between NPs is largely determined by their concentration in the dispersed system. Almost all NPs when they enter the aquatic environment are characterized by the formation of conglomerates (no longer nanoscale values) with subsequent sedimentation and elimination from active processes [15].

The number of tests, according to the existing requirements (Regulation EC №1907/2006) [16], depends on the volume of production. In the production of one to 10 tons per year, it is necessary to conduct short-term tests with aquatic invertebrates (the predominant species are daphnia) and photosynthetic organisms (mainly algae). In the case of production of more than 10 tons per year, additional shortterm tests are required, for example, on fish and the study of oxygen consumption by activated sludge microorganisms. The above studies on water bodies should also be performed as long-term experiments for substances produced in excess of 100 tons per year, as well as tests involving fish at an early stage of life, short-term tests on embryonic embryos, fry. With the production of more than 100 tons per year, short-term tests are required for such land dwellers as invertebrates, plants and soil microorganisms. Finally, if the production of a given substance exceeds 1000 tonnes per year, long-term toxicity tests should be performed on invertebrates, plants, sediments and birds in addition to all the aforementioned aquatic and terrestrial studies.

One of the most important characteristics of nanoparticles is their tendency to form agglomerates - the adhesion of nanoparticles, which increases the size of the particles in solution, respectively, change their physical and chemical properties. On the example of two-day-old fry and young rainbow trout, it was found that increasing the agglomeration of silver nanoparticles leads to a decrease in toxicity $[17,18]$. Suspensions of powdered nanosilver are more prone to agglomeration in comparison with colloidal silver. Thus, colloidal sil- ver was 60-100 times more toxic than suspensions of powdered substance; depending on the exposure time, the $\mathrm{EC}_{50}$ values were 0,25$2,75 \mathrm{mg} / \mathrm{l}$ and $28,25-186,42 \mathrm{mg} / 1$, respectively.

To avoid agglomeration and precipitation of nanoparticles, various stabilizing substances and coatings are used, which contribute, on the one hand, to maintaining the dimensionality of nanoparticles, and on the other - can increase their toxicity. Thus, when comparing the level of toxicity of silver hydrosols and nanoparticles with different coatings (citrate, polyvinylpyrrolidone-PVP and EDTA), in relation to aquatic organisms, it was found that the most toxic of the presented samples was colloidal silver, and the least toxic were silver nanoparticles covered with PVP [19]. Comparing the ability of nanoparticles coated with PVP and citrate to accumulate in monoand multilayers of primary gill cells of rainbow trout, it was found that the absorption through the monolayer epithelium of nanoparticles with citrate is higher than with PVP, but nanoparticles with PVP accumulate faster. Also, after exposure to both types of nanoparticles, an increased level of glutathione was noted, as expected, because this is a reaction to oxidative stress [20,21].

The results of the effect of nanosized particles on the various test objects we obtained are quite ambiguous. This is due not only to the lack of uniform standards for research, biotesting of nanoparticles, the choice of different test functions and experimental conditions, but also the characteristics of the nanoparticles, their changes due to technological and laboratory procedures and manipulations.

Technogenic nanoparticles can have both positive and negative effects on various test objects or not detect it. According to the modern scientific literature, the reactions of organisms to the action of nanoparticles are insufficiently studied; in the literature, contradictory results of the influence of nanoparticles of different sizes on the performance of test organisms are given. The corresponding reactions of enzyme systems in the presence of nanoparticles are practically not studied. All these issues need further study. Given the changes in the properties and activity of NPs (even through laboratory manipulations), it is essential to pre-assess their potential danger for the development of a warning system. This will minimize potential risks even before their accurate 
assessment as a result of experimental tests [22]. Targeted testing can provide a broad coverage of nanoproducts, reduce the cost and time of research, as well as the number of animals used in experiments [23]. Targeted testing can be used to study the mechanisms to detect a chemical that causes toxicity, and to help compare in vitro observations with molecular, cellular, or physiological effects in animals.

It is known that the interaction of chemical compounds with specific receptors, enzymes, other discrete proteins and nucleic acids or with a wide range of molecules causes adverse reactions of biological systems [24]. And the development of in vitro test systems aimed at studying the molecular interactions of chemicals with cellular components, due to the need to quickly obtain information about the dangers of products being developed and reduce significant costs in the development of research objects [25, 26].

Cell-free or biochemical tests can provide positive and reliable results reproduced in different laboratories [27]. A wide range of cellfree tests have been developed and used in pharmaceutical, biomedical and academic laboratories [28-31]. Targeted testing can be used to study the mechanisms by which a chemical causes toxicity. It will help to compare in vitro observations with molecular, cellular or physiological effects in animals [23].

The new strategy, in which traditional laboratory animal studies have been replaced by a wide range of new toxicity testing methods, is based primarily on in vitro assays, computational methods and targeted animal tests. This is a difficult task. This strategy involves research aimed at understanding and taking into account the full range of perturbations that can lead to NPs toxicity to humans, caused in particular by their dimensional and structural features and changes. Of particular note are studies that help to understand how individual differences (e.g., diet, health, or stage of life) and exposure levels may affect biological responses and toxicity. To date, significant progress has been made in developing and adopting a wide range of screening methods for chemical pollutants. But some of them, in particular the cell culture method, have a number of important limitations due to their extreme sensitivity to environmental conditions. According to forecasts, the global nanotechnology market will grow by about 18 percent per year, by 2025 its volume will be somewhere around 174 billion US dollars [32]. Increasing the production and use of specially designed nanomaterials in various industries is likely to lead to their spontaneous release into the environment at any time during the product life cycle [33].

Since the safety assessment of nanoparticles and nanomaterials is difficult due to uncertainties associated with really low levels of exposure, as well as changes in particle properties (including dispersion and surface properties) in biological matrices and laboratory manipulations, the position on their study in exposure systems in vitro has become more attractive. The use of alternative toxicological models (cell cultures, rapid tests, etc.) allows to obtain information about the toxicity and hazards of chemicals or materials in less expensive ways or approaches, in a shorter time and more humanely from the standpoint of bioethics compared to traditional experimental methods, laboratory animals. In vitro experiments can be used to screen nanosized materials as a "vector" for in-depth experimental studies in vivo.

\section{REFERENCES}

1. Onishhenko GG, Tutel'yan VA, Gmoshinskij IV, Khotimchenko SA. Razvitie sistemy`oczenki bezopasnosti i kontrolya nanomaterialov i nanotekhnologij v Rossijskoj Federaczii. Gigiena i sanitariya. 2013; 1: 4-11.

2. Vance ME, Kuiken T, Vejerano EP, McGinnis SP, Hochella MF Jr, Rejeski D et all. Nanotechnology in the real world: Redeveloping the nanomaterial consumer products inventory. Beilstein. J. Nanotechnol. 2015; 6: 1769-80.

3. Riya Jain, Deepak Sharma. Applications and Ethical Issues of Nanotechnology in Real World. Journal of Web Engineering \& Technology. 2019; 6(2): 25-8.

4. Prognoz nauchno-tekhnologicheskogo razvitiya Rossii:
2030. Novy`e materialy`i nanotekhnologii. Pod red. LM Gokhberga, AB Yaroslavczeva. M.: Ministerstvo obrazovaniya i nauki Rossijskoj Federaczii, Naczional’ny’j issledovatel'skij universitet "Vy'sshaya shkola e'konomiki». 2014. $52 \mathrm{~s}$.

5. Ostroumov SA. Testirovanie toksichnosti khimicheskikh veshhestv bez ispol’zovaniya zhivotny`kh. E’kologicheskaya khimiya 2016; 25(1): 5-15.

6. Kotelevczev SV, Matorin DN, Sadchikov AP. E`kologicheskaya toksikologiya i biotestirovanie vodnoj sredy'. Moskva: INFRA-M; 2015, 252 s.

7. Ostroumov SA. Toxicity testing of chemicals without use of 
animals. Russian Journal of General Chemistry. 2016; 86: 2933-41.

8. Zariczkaya EV, Polozova EV, Bogacheva AS. Sovremenny`e al'ternativny'e toksikologicheskie metody' issledovaniya $\mathrm{i}$ perspektivy' ikh ispol'zovaniya v prakticheskoj deyatel 'nosti. Gigiena i sanitariya. 2017; 96(7): 671-74. DOI: http://dx.doi.org/10.18821/0016-9900-2017-96-7671-674

9. E’kspress-oczenka toksichnosti otkhodov proizvodstva i potrebelniya na kul'ture kletok mlekopitayushhikh. Federal 'ny`j czentr gigieny' i e'pidemiologii Rospotrebnadzora. M.: 2008, 12 s.

10. Leonenko NS, Leonenko OB. Toxic effects of nanoparticles. Biotechnologia Acta. 2017; 10(2): 7-19. https://doi.org/10.15407/biotech10.03.007.

11. Costanza Rovida, Shoji Asakura, Mardas Daneshian, Hana Hofman-Huether, Marcel Leist, Leo Meunier et al. Testing in the 21st Century Beyond Environmental Chemicals. ALTEX. 2015; 32(3): 171-81. doi: 10.14573/ altex. 1506201.

12. Tomilina II, Gremyachikh VA, Grebenyuk LP, Golovkina EI, Klevleeva TR. Toksikologicheskoe issledovanie metallicheskikh i metallooksidny`kh nanochasticz. Trudy` IBVV RAN. 2017; 77(80): 105-23.

13. Dubinskaya VA, By`kov VA. Molekulyarny`e biotest-sistemy` in vitro v oczenke farmakologicheskoj aktivnosti biomassy` kul'tur kletok rastenij. Voprosy` biologicheskoj, mediczinskoj i farmaczevticheskoj khimii. 2018; 1: 3-6.

14. Lapin AA, Govorkova LK, Chugunov YuV, Potapov VV, Zelenkov VN, Sorokina AA. Perspektivy' primeneniya nanodispersnogo kremnezema v ry'bovodstve. Butlerov Communications. 2015; 44: 5-9.

15. Makarov DV. E'kologicheskaya bezopasnost' nanoporoshkov. Vestnik KRAUNCz. Fiziko-matematicheskie nauki. 2013; 6(1): 73-80.

16. REGULATION (EC) No 1907/2006 OF THE EUROPEAN PARLIAMENT AND OF THE COUNCIL.

17. Kalbassi M, Johari S, Soltani M, Yu I. Particle size and agglomeration affect the toxicity levels of silver nanoparticle types in aquatic environment. Ecopersia. 2013; 1(3): 273-90.

18. Polonskij VI., Asanova AA. Oczenka vozdejstviya nanochasticz dioksida titana na zhivy`e organizmy`. Teoreticheskie problemy' e'kologii. 2018; 3: 5-11. doi: 10.25750/1995-4301-2018-3-005-011.

19. Kennedy AJ, Hull MS, Bednar AJ, Goss JD, Gunter JC et al. Fractionating nanosilver: importance for determining toxicity to aquatic test organisms. Environmental science \& technology. 2010; 44(24): 9571-7. doi: 10.1021/ es1025382. Epub 2010 Nov 17.

20. Farkasa J, Peter H, Christian P, Urrea J, Hassellov M, Tuoriniemi $\mathrm{J}$ et al. Characterization of the effluent from a nanosilver producing washing machine. Environment international. 2011; 37(6): 1057-62. https://doi.org/10.1016/ j.envint.2011.03.006.
21. Polonskij VI, Asanova AA. Vliyanie nanochasticz serebra na biologicheskie ob 'ekty'. Vestnik KrasGAU. 2018; 6: 271-6.

22. Zhilinskij EV. Nanotekhnologii v zdravookhranenii oczenka riskov i strategiya bezopasnosti. Vlast’. 2017; 25(3): 79-86.

23. Krewski D, Andersen ME, Tyshenko MG, Krishnan K, Hartung T, Boekelheide $\mathrm{K}$ et al Toxicity testing in the 21st century: progress in the past decade and future perspectives. Archives of Toxicology. 2020; 94: 1-58 https://doi.org/ 10.1007/s00204-019-02613-4.

24. Bowes J, Brown AJ, Hamon J, Jarolimek W, Sridhar A, Waldron $\mathrm{G}$ et al. Reducing safety-related drug attrition: The use of in vitro pharmacological profiling. Nat. Rev. Drug Discov. 2012; 11(12): 909-22. DOI: 10.1038/nrd3845.

25. Bento AP, Gaulton A, Hersey A, Bellis LJ, Chambers J, Davies $\mathrm{M}$ et al. The ChEMBL bioactivity database: An update. Nucleic Acids Res. 2014; 42. D1083-D1090. doi: 10.1093/nar/gkt1031.

26. Papadatos G, Gaulton A, Hersey A, Overington JP. Activity, assay and target data curation and quality in the ChEMBL database. J. Comput. Aided Mol. Des. 2015; 29(9): 885-96. doi: 10.1007/s10822-015-9860-5

27. Zhang Z, Guan N, Li T, Mais DE, Wang M. Quality control of cell-based highthroughput drug screening. Acta. Pharma. Sin. B. 2012; 2(5): 429-38. https://doi.org/10.1016/ j.apsb. 2012.03.006.

28. Xia W, Wan YJ, Wang X, Li YY, Yang WJ, Wang CX et al. Sensitive bioassay for detection of PPAR $\alpha$ potentially hazardous ligands with gold nanoparticle probe. J. Hazard Mater. 2011; 192(3): 1148-54. doi: 10.1016/j.jhazmat.2011.06.023.

29. Mehta J, Rouah-Martin E, Van Dorst B, Maes B, Herrebout W, Scippo ML et al. Selection and characterization of PCBbinding DNA aptamers. Anal. Chem. 2012; 84(3): 166976. https://doi.org/10.1021/ac202960b.

30. Landry JP, Malovichko G, Zhu XD. High-throughput doseresponse measurement using a label-free microarray-inmicroplate assay platform. Anal. Chem. 2015; 87(11), 5640-48 https://doi.org/10.1021/acs.analchem.5b00720/

31. McKinstry-Wu AR, Bu W, Rai G, Lea WA, Weiser BP, Liang DF et al. Discovery of a novel general anesthetic chemotype using highthroughput screening. Ane-sthesiology 2015; 122(2): 325-33. https://doi.org/ 10.1097/ALN.0000000000000505

32. Global Nanotechnology Market Worth USD 173.95 Billion by 2025 - Analysis, Technologies \& Forecasts Report 2016-2025. - Business Wire 2016. http://www.businesswire.com/news/ home/20160928005566/en/GlobalNanotechnology-Market-Worth-USD173.95-Billion

33. Nagai H, Toyokuni S. Differences and similarities between carbon nanotubes and asbestos fibers during mesothelial carcionogensis: Shedding light on fiber entry mechanism. Cancer Science. 2012; 103(8): 1378-90. https://www.researchgate.net/publication/224924547. doi: 10.1111/j.1349-7006.2012.02326.x. 


\section{ДО ПРОБЛЕМ ТЕСТУВАННЯ ТОКСИЧНОСТІ НАНОРОЗМІРНИХ ОБ'ЕКТІВ (огляд літератури)}

О.Б. Леоненко

ДУ «Інститут медицини праці імені Ю.І. Кундієва Національної академії медичних наук України , м. Київ, Україна

PEЗЮМЕ. Мета. Представити та узагальнити дані з проблем оцінки токсичності та небезпеки нанорозмірних частинок через особливості їхньої активності і мінливості, які доводять необхідність розробки вектора досліджень в умовах іп vitro. Матеріали та методи. Цільове тестування може забезпечити широке охоплення нанопродукціі, зменшить вартість $і$ час проведення досліджень, а також кількість тварин, що використовуються в експериментах. Пропонуються до використання різні модельні тест-системи, застосування яких можливе для виявлення шкідливих впливів техногенних наноматеріалів, так само як і для інших хімічних речовин: клітинні та субклітинні елементи (мітохондрії, мікросоми, ДНК, судини хоріоалантоїсної оболонки), органи лабораторних тварин, лабораторні тварини, найпростіші (одноклітинні) організми, мікроорганізми, різні гідробіонти, рослини, комахи, сперма великої рогатої худоби.

Біотестування - один із прийомів дослідження в галузі токсикології, що використовується для встановлення ступеня токсичної дії хімічних, фізичних і біологічно несприятливих чинників, потенційно небезпечних для людини і компонентів екосистем.

Аналітичний огляд наукових публікацій виконаний з використанням реферативних баз даних наукових бібліотек Риь Меd, Medline і текстових баз даних наукових видавництв Elsevier, Pub Med, Central, BMJ group та інших VIP-баз даних.

Результати та висновки. Останнім часом у публікаціях акцентується увага, що прояви біологічних ефектів залежать від зміни характеристик і властивостей наноматеріалів. Ці факти неможллво врахувати при стандартних токсикологічних дослідженнях. Одним із шляхів інтенсифікації випробувань $і$ зниження їхньої собівартості може бути застосування прискорених токсикологічних досліджень на простих біологічних системах (моделях). У зв'язку з цим розробка і впровадження альтернативних методів іn vitro стала одним із провідних напрямків токсикологічних досліджень наноматеріалів.

Ключові слова: наночастинки, токсичність, тестування.

\section{К ПРОБЛЕМАМ ТЕСТИРОВАНИЯ ТОКСИЧНОСТИ НАНОРАЗМЕРНЫХ ОБЪЕКТОВ (обЗОр лИтературЫ)}

О.Б. Леоненко

ГУ «Институт медицины труда имени Ю.И. Кундиева

Национальной академии медицинских наук Украины», г. Киев, Украина

PЕЗЮМЕ. Цель. Представить и обобщить данные по проблемам оценки токсичности и опасности наноразмерных частии через особенности их активности и изменчивости, которые доказывают необходимость разработки вектора исследований в условиях in vitro.

Материалы и методы. Целевое тестирование может обеспечить широкий охват нанопродукции, уменьшит стоимость и время проведения исследований, а также количество животных, используемых в экспериментах. Предлагаются к использованию различные модельные тест-системы, применение которых возможно для выявления вредных воздействий техногенных наноматериалов, так же как и для других химических веществ: клеточные и субклеточные элементы (митохондрии, микросомы, ДНК, сосуды хориоалантоисной оболочки), органы лабораторных животных, лабораторные животные, простейшие (одноклеточные) организмы, микроорганизмы, различные гидробионты, растения, насекомые, сперма крупного рогатого скота.

Биотестирование - один из приемов исследования в области токсикологии, используемый для установления степени токсического воздействия химических, физических и биологически неблагоприятных факторов, потенциально опасных для человека и компонентов экосистем.

Аналитический обзор научных публикаций выполнен с использованием реферативных баз данных научных библитек Риь Med, Medline и текстовых баз данных научных издательств Elsevier, Pub Med, Central, BMJ grouр и других VIP-баз данных. Результаты и выводы. В последнее время в публикациях акцентируется внимание, что проявления биологических эффектов зависят от изменения характеристик и свойств наноматериалов. Эти факты невозможно учесть при стандартных токсикологических исследованиях. Одним из путей интенсификации испытаний и снижения их себестоимости может быть применение ускоренных токсикологических исследований на простых биологических системах (моделях). В связи с этим разработка и внедрение альтернативных методов in vitro стала одним из ведущих направлений токсикологических исследований наноматериалов.

Ключевые слова: наночастицы, токсичность, тестирование.

Received 10/28/2020 